\title{
Experimental Study on Fibre Reinforced Eco-Friendly Self Compacting Concrete
}

\author{
Selvarani ${ }^{1}$, Angeline Prabhavathy ${ }^{2}$ \\ ${ }^{I}$ Department of Civil Engineering, DMI College of Engineering, Chennai. India \\ ${ }^{2}$ Department of Civil Engineering, Hindustan University, Chennai. India
}

\begin{abstract}
Self-compacting Concrete (SCC) is a concrete that flows under its own weight and does not require any external vibration for compaction. Due to the many advantages of this concrete, it is suitable for situations where congested reinforcement is used. In this experimental study, selfcompacting concrete was developed for M30 grade of concrete using 25\% of GGBS (Ground- Granulated Blastfurnace Slag) by weight of cement as partial replacement of cement and an optimum content of Polypropylene fibres at $1.00 \mathrm{Kg}$ per cubic meter of concrete was also added to increase the strength of concrete. Waste Foundry Sand and Pond ash were used as partial replacement of fine aggregate (river sand) at $0 \%, 10 \%, 20 \%$, and $30 \%$ by weight. The Optimum content of Pond ash was arrived at 30\% replacement. Pond ash above $30 \%$ has not satisfied the EFNARC Specification and decreased the hardened concrete properties of SCC. Viscosity Modifying Agent and modified polycarboxylates based Superplasticizer are the chemicals used in the self-compacting concrete. The Fresh concrete fulfilled the EFNARC Specification. Cube specimens of size $150 \times 150$ × $150 \mathrm{~mm}$, cylindrical specimens of size $150 \times 300 \mathrm{~mm}$ and prism specimens of size $100 \times 100 \times 400 \mathrm{~mm}$ were prepared and their compressive strength, split tensile strength, flexural strength at 7 and 28 days and the durability properties were evaluated. The fibre reinforced self compacting concrete, Mix VIII, obtained with $30 \%$ Pond ash and $20 \%$ foundry sand used as replacement for river sand and $25 \%$ of GGBS as a replacement of cement and $1.00 \mathrm{~kg} / \mathrm{m}^{3}$ fibres has the maximum compressive strength and split tensile strength with a marginal decrease in flexural strength by $3 \%$ when compared to the conventional self compacting concrete at 28 days. Mix VIII (PA-30\%+WFS-20\%) had the maximum compressive strength after additional 28 days of acid attack and the least percentage loss in weight $(1.80 \%)$ when exposed to sulphate attack for 28 days. The fibre reinforced self compacting concrete with $30 \%$ Pond ash and $20 \%$ foundry sand used as replacement for river sand exhibited good durability performance in terms of water absorption, acid attack and sulphate attack. It is also economical and environmentfriendly and can be effectively used in construction .
\end{abstract}

Keywords : SCC (Self Compacting Concrete), FRSCC(Fiber Reinforced Self Compacting Concrete) PA (pond ash), NS (Natural sand), polypropylene fibres, foundry sand.

\section{INTRODUCTION}

Self-Compacting Concrete (SCC) is an innovative concrete which flows under its own weight and fills the formwork completely and achieves full compaction even in the presence of congested reinforcement. Vibration is not required for Self-
Compacting Concrete for placing and compaction. It has improved the construction practice making it a very attractive solution for Civil Engineering construction. Self-compacting concrete was developed in Japan in the year 1980. In SCC, powder content is high and volume of fine aggregate is greater than the volume of the coarse aggregate. Usually the fine aggregate volume to coarse aggregate volume ratio is taken as 60:40 for the reason that finer particles increase the flowing property of concrete and increase in coarser particles blocks the flow of concrete. Addition of super plasticizer is necessary for this type of concrete to increase the flow of concrete and Viscosity Modifying Agent is used in SCC to maintain the homogeneity of concrete mix. SCC acts as an environment friendly concrete by reducing the noise pollution and ensures safety of the labourers at site. Pond ash is a by- product from thermal power station. Pond ash consists of fused coarser particles and appear like volcanic lava. Due to its pozzolanic nature it has potential to be used as supplementary and alternative material in construction industry. The metal foundries use large amounts of sand for metal casting process. Foundries successfully recycle and reuse the sand many times during the casting process. Use of pond ash and Foundry sand in self compacting concrete not only result in conservation of natural aggregate but also solves the problem of disposal of huge quantity of pond ash and foundry sand which are produced regularly and kept in abundance. The collection and disposal of residues such as rice husk ash, bottom ash, fly ash, pond ash, foundry sand and sludge produced as wastes from various industries has become an environmental problem. However, these industrial wastes could be utilized in concrete. With the advancement in technology, the world has experienced a revolution in the construction industry putting eco-friendly materials into use. The compressive strength is high compared to conventional mix. Mix proportions for SCC differs from those of ordinary concrete which has more powder content and less content of coarse aggregate. Supplementary cementitious materials such as fly ash, silica fume and blast furnace slag are normally used in SCC. We can reduce the cost of concrete without compromising the strength. This concrete is more useful in the areas where the cost of sand is expensive. In this study, SCC mix was arrived based on EFNARC guidelines and using various mix combinations. An experimental study was made on the properties of SCC where pond ash and foundry sand which are waste materials, had been used as replacement for fine aggregate in concrete. Another material used is a synthetic fibre, polypropylene which is available commercially as Recron fibre at very cheap rate making the self-compacting concrete quite economical.

Attar et al. replaced the natural sand by $5 \%$ to $60 \%$ foundry 
sand in self-compacting concrete and tested for various fresh and hardened properties of concrete. The results showed a marginal increase in compressive strength when the partial replacement was $20 \%$ and a decrease in compressive strength when the replacement percentage exceeded $60 \%$. Siddique et al. replaced natural sand with four percentages $(0 \%, 10 \%, 15 \%$, $20 \%$ ) of waste foundry sand by weight. Compression test results and split tensile strength on the 7th, 28th and 56th days showed that there was an increase in the compressive strength and split tensile strength of self- compacting concrete by incorporating waste foundry sand (WFS) as partial replacement for river sand up to $15 \%$. M30 grade concrete mix was obtained. Increase in the 28th day compressive strength from $37.06 \mathrm{MPa}$ to $43.03 \mathrm{MPa}$ was observed on $15 \%$ replacement of fine aggregate with WFS and beyond $15 \%$ replacement, the strength decreased, but was still higher than the control concrete. Compressive strength increased with increase in the age of concrete. Similar results were obtained by Siddique et al. that flexural strength also increased with an increase in WFS content $15 \%$ and concluded that the WFS could be conveniently used in making good quality concrete. Kamal et al. studied the optimum content of fibres (steel and polypropylene fibres) used in SCC and the effect of different fibres on the fresh and hardened properties of SCC. The mechanical properties such as compressive strength, flexural strength and impact strength of fiber-reinforced selfcompacting concrete were evaluated. From the results it was found that the optimum dosage of steel and polypropylene fiber was $0.75 \%$ and $1.0 \%$ of the cement content respectively and the impact strength also improved due to the use of fibres. Waysal et al. found that the pond ash can be used as a partial replacement for fine aggregate in self-compacting concrete. Sand was replaced by pond ash at 0\%, 20\%, 40\%, 60\%, 80\% and $100 \%$ by weight and the optimum percentage was observed at $40 \%$ replacement of sand by pond ash. The compressive strength and the split tensile strength at 7,28, and 56 days were observed and it was found that $40 \%$ of sand replacement with pond ash increased the compressive strength and the split tensile strength compared to normal selfcompacting concrete. But the compressive strength and the split tensile strength decreased with increasing pond ash replacement beyond $40 \%$. Shivakumar et al. investigated the hardened properties of concrete with $30 \%$ replacement of cement with fly ash in M20 mix. Six SCC mixes with 0 to $100 \%$ (at an interval of 20\%) were prepared by partial replacement of fine aggregate using pond ash. Fresh properties and hardened properties of these concrete mixes were determined. It was concluded that a replacement of natural sand by pond ash could be done up to $40 \%$ as the compressive strength and split tensile strength were high at SCC40 and water absorption was low at SCC40 (0.34\%). Saranya et al. studied the possibility of using industrial by-products like Ground Granulated Blast Furnace Slag (GGBS and Fly Ash (FA)) in the preparation of SCC mixes of M30 grade. The optimum amount of GGBS in concrete was found to be $40 \%$ for compressive strength and $50 \%$ for tensile strength. There was a significant reduction in the flexural strength at $60 \%$ GGBS content. Thus the optimum amount of GGBS in concrete was found to be $40 \%$. Anushai et al. studied the effect of mineral admixtures as supplementary cementatious material on the mechanical properties of self compacting concrete. The investigation was carried out on M20 and M35 concrete with partial replacement of cement by GGBS and fly ash.
Conventional concrete and SCC mixes with varying percentages of fly ash (20\% and 25\%) and GGBS (40\% and 50\%) and combination of fly ash and GGBS were investigated. Experimental results showed that there was an increase in the compressive strength of self-compacting concrete at $40 \%$ GGBS and $20 \%$ fly ash when compared to traditional self compacting concrete.

In this experimental study, tests were conducted to find the mechanical properties of concrete such as the cube compressive strength, split tensile strength, flexural strength and durability properties of the cube, cylinders and beams specimens.

\section{MATERIALS}

\section{A . Cementitious Materials}

\section{Cement}

The ordinary Portland cement of Grade 53 conforming to IS12269:1987 was used.

\section{Ground Granulated Blast Furnace Slag (GGBS)}

Blast furnace slag is a by-product obtained from the blast furnaces in the manufacture of iron. The Slag which is obtained by grinding the granulated blast furnace is highly pozzolanic in nature. Cement replacement levels of slag is much higher than that of other pozzolanic materials such as fly ash and silica fume. The GGBS has higher ' $\mathrm{CaO}$ ' content than other pozzolanas. The physical properties of GGBS are given in Table 1

Table 1. Physical Properties of GGBS

\begin{tabular}{|l|c|}
\hline Test conducted & Result \\
\hline Fineness by Blaine's air permeability $\left(\mathrm{m}^{2} / \mathrm{kg}\right)$ & 321 \\
\hline Specific Gravity & 2.95 \\
\hline Wet sieve analysis \% retained on $(45 \mu)$ & $2.90 \%$ \\
\hline
\end{tabular}

\section{B . Fine Aggregates}

\section{Natural River Sand}

The river sand available nearby was used as fine aggregate. It satisfied the specifications of IS: 383-1970(zone II).The physical properties of the natural river sand used are listed in Table 2 .

\section{Pond ash}

The pond ash used was obtained from North Madras Thermal power station. The various tests were carried out .It was used as fine aggregate as a replacement for natural river sand in SCC. Pond ash content was varied as $0 \%, 10 \%, 20 \%$ and $30 \%$ by the weight of fine aggregate. The physical properties of the pond ash used are listed in Table 2.

\section{Foundry Sand}

Foundry sand confirming to zone - II as per IS 383: 1970 was used as fine aggregate as a replacement for natural river sand in SCC. It was clean, inert and free from organic matter, silt.The foundry sand content was varied as $0 \%, 10 \%, 20 \%$ and $30 \%$ by the weight of fine aggregate.The foundry sand sample is shown in Figure 1. The physical properties of the foundry sand used are listed in Table 2 . 
International Journal of Engineering Research and Technology. ISSN 0974-3154, Volume 13, Number 9 (2020), pp. $2365-2373$

(C) International Research Publication House. https://dx.doi.org/10.37624/IJERT/13.9.2020.2365-2373

Table 2. Physical properties of Pond ash, Foundry Sand and Natural sand

\begin{tabular}{|l|c|c|c|}
\hline Property & Pond Ash & $\begin{array}{c}\text { Used } \\
\text { Foundry } \\
\text { sand }\end{array}$ & $\begin{array}{c}\text { Natural } \\
\text { River } \\
\text { sand }\end{array}$ \\
\hline $\begin{array}{l}\text { Specific } \\
\text { gravity }\end{array}$ & 2.10 & 2.40 & 2.61 \\
\hline $\begin{array}{l}\text { Bulk relative } \\
\text { density } \\
(\mathrm{kg} / \mathrm{m} 3)\end{array}$ & 1780 & 1589 & 1460 \\
\hline $\begin{array}{l}\text { Absorption } \\
(\%)\end{array}$ & 1.20 & 0.45 & 2.50 \\
\hline $\begin{array}{l}\text { Moisture } \\
\text { content(\%) }\end{array}$ & Nil & 2.25 & 1.50 \\
\hline $\begin{array}{l}\text { Fineness } \\
\text { modulus }\end{array}$ & 2.35 & 2.15 & 2.48 \\
\hline $\begin{array}{l}\text { Sieve } \\
\text { analysis }\end{array}$ & Zone-II & Zone- II & Zone- II \\
\hline
\end{tabular}

\section{Coarse Aggregates}

The coarse aggregate size mainly influences the fresh characteristics of SCC. When the maximum size of the coarse aggregates used in SCC are increased, the flow ability and passing ability of the concrete decreases and segregation increases. Hence to achieve good flow ability and passing ability , the maximum size of coarse aggregates are taken as $12 \mathrm{~mm}$. Blended aggregates of size $12 \mathrm{~mm}$ to $6 \mathrm{~mm}$ were used as coarse aggregate.

\section{Water}

Clean water satisfying the requirements of IS 456:2000 was used. The water was clean and free from any visible impurities.

\section{E. Polypropylene fibres}

Recron $3 \mathrm{~S}$ fibres was used as a reinforcement material. It makes the concrete homogenous, improves ductility, compressive strength and flexural strength and also improves the ability to absorb more energy. Use of uniformly dispersed Recron fibres reduces segregation resulting in a more homogeneous mix and leads to better strength, durability and reduces permeability. The polypropylene fibre is shown in Figure 2.

\section{F. Superplasticizer}

More cohesiveness can be obtained by incorporating a viscosity-modifying admixture along with a high range water reducing admixture to control bleeding, segregation, and surface settlement (Khayat et al., 1997). Super Plasticizer (Master Glenium SKY 8233) is an admixture based on modified polycarboxylic ether (PCE) which helps to produce concrete with longer workability retention which eliminates vibration and free of chloride and has low alkali content. The use of modified polycarboxylates based superplasticizer improves the flowability of the concrete.

\section{G. Viscosity Modifying Agent (Master Matrix 102)}

The organic liquid viscosity modifying agent was used to produce concrete with enhanced viscosity and controlled rheological properties.

\section{METHODOLOGY}

The various mixes of the materials were tested as per EFNARC guidelines. Trail mixes were made for maintaining flow ability for self-compactability and segregation. Tests were conducted

for fresh properties such as T- Slump flow, T50mm - Slump flow, V - Funnel test, L - Box test, V5min - funnel test and J ring test. The final mix of self-compacting concrete was developed and the casting of the specimens was done in four stages. At the first stage, GGBS (Ground- Granulated Blast-furnace Slag)at $0 \%, 5 \%, 10 \%, 15 \%, 20 \%, 25 \%$ and $30 \%$ by weight of cement as partial replacement of cement was made and the optimum percentage of GGBS was obtained as $25 \%$. In the second stage, with optimum dosage of GGBS, polypropylene fibres were added and the optimum dosage of fibres was obtained as $1.00 \mathrm{Kg} / \mathrm{m} 3$. At the third stage, with the optimum dosage of GGBS and polypropylene fibres, the percentage of pond ash in self compacting concrete was used as a replacement for natural river sand as fine aggregate and the optimum percentage of pond ash was obtained as $30 \%$. In the fourth stage, with optimum dosages of GGBS, polypropylene fibres and pond ash, foundry sand was used as a replacement for natural river sand in self compacting concrete. The behavior of SCC in compression, split tension and flexure were investigated. For the hardened properties, the cubical specimens of size $150 \times 150 \times 150 \mathrm{~mm}$ were cast for compressive strength and cylindrical specimen of size $150 \times 300 \mathrm{~mm}$ were cast for split tensile strength and prism specimens of size $100 \times 100 \times 400 \mathrm{~mm}$ were cast for flexural strength. The compressive, tensile and flexural strength were evaluated at 7 and 28 days



Fig.1. Foundry sand



Fig. 3. L Box test

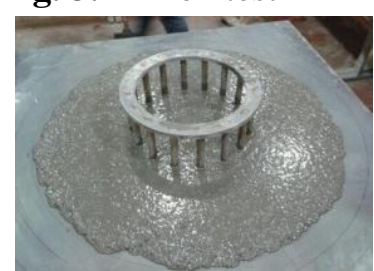

Fig. 5. J Ring test

\section{WORKABILITY TEST}

The mix proportions are shown in Table 3. The tests for workability such as slump flow test, V-funnel test, L-box test and J Ring test were given in Table 4.The Figures 3,4 and 5 show the L-box, slump flow and $\mathrm{J}$ Ring tests conducted on FRSCC 
Table 3. Mix Proportion

\begin{tabular}{|c|c|c|c|c|c|c|c|c|c|c|c|}
\hline \multirow[b]{2}{*}{ 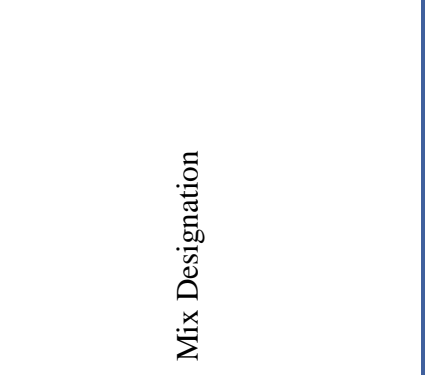 } & \multirow[b]{2}{*}{ 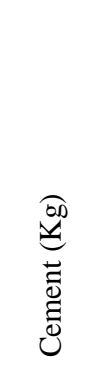 } & \multirow[b]{2}{*}{ 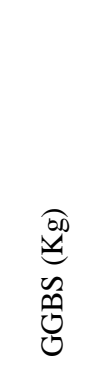 } & \multirow[b]{2}{*}{ 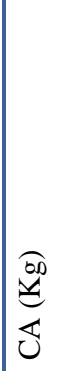 } & \multicolumn{3}{|c|}{ 压苞 } & \multirow{2}{*}{ 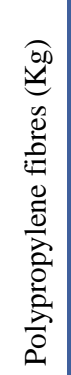 } & \multirow[b]{2}{*}{ 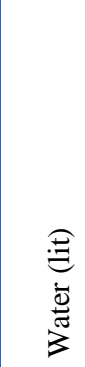 } & \multirow[b]{2}{*}{$\begin{array}{l}\therefore 0 \\
\text { के }\end{array}$} & \multirow[b]{2}{*}{$\sum_{>}^{\infty}$} & \multirow{2}{*}{ 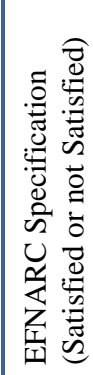 } \\
\hline & & & & $\tilde{z}$ & $\overleftrightarrow{\Omega}$ & $\sum_{3}^{\infty}$ & & & & & \\
\hline Mix I (Riversand-100\%) & 332 & 111 & 717 & 990 & - & - & - & 189 & 1.10 & 0.20 & $\mathrm{~S}$ \\
\hline Mix II (Riversand-100\%+Fibres) & 332 & 111 & 717 & 990 & - & - & 1 & 189 & 1.30 & 0.25 & $\mathrm{~S}$ \\
\hline $\begin{array}{l}\text { Mix III(RiverSand-90\%+PA- } \\
10 \%+\text { Fibres) }\end{array}$ & 332 & 111 & 717 & 891 & 99 & - & 1 & 189 & 1.30 & 0.25 & $\mathrm{~S}$ \\
\hline $\begin{array}{l}\text { MixIV ((RiverSand-80\%+PA- } \\
20 \%+\text { Fibres) }\end{array}$ & 332 & 111 & 717 & 792 & 198 & - & 1 & 189 & 1.35 & 0.25 & $\mathrm{~S}$ \\
\hline $\begin{array}{l}\text { Mix V(RiverSand-70\%+PA- } \\
\text { 30\%+Fibres) }\end{array}$ & 332 & 111 & 717 & 693 & 297 & - & 1 & 189 & 1.40 & 0.25 & $\mathrm{~S}$ \\
\hline $\begin{array}{l}\text { Mix VI (RiverSand-60\%+PA- } \\
40 \%+\text { Fibres) }\end{array}$ & 332 & 111 & 717 & 594 & 396 & - & 1 & 189 & 1.40 & 0.30 & N S \\
\hline $\begin{array}{l}\text { MixVII (RiverSand-60\%+PA- } \\
\text { 30\%+WFS-10\%+Fibres) }\end{array}$ & 332 & 111 & 717 & 594 & 297 & 99 & 1 & 189 & 1.45 & 0.30 & S \\
\hline $\begin{array}{l}\text { Mix VIII (RiverSand-50\%+PA- } \\
\text { 30\%+WFS-20\%+Fibres) }\end{array}$ & 332 & 111 & 717 & 495 & 297 & 198 & 1 & 189 & 1.50 & 0.30 & $\mathrm{~S}$ \\
\hline $\begin{array}{l}\text { Mix IX (RiverSand-40\%+PA- } \\
\text { 30\%+WFS-30\%+Fibres) }\end{array}$ & 332 & 111 & 717 & 396 & 297 & 297 & 1 & 189 & 1.55 & 0.35 & N S \\
\hline
\end{tabular}

Table 4. Test Workability Results

\begin{tabular}{|c|c|c|c|c|c|c|c|c|c|c|}
\hline Mix Designation & 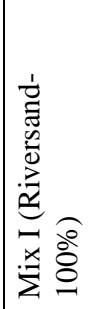 & 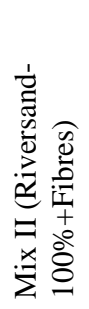 & 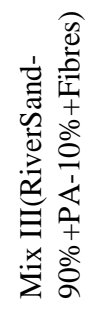 & 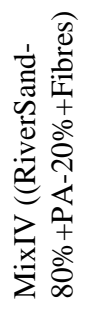 &  & 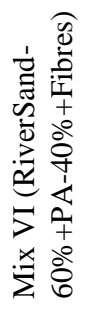 & 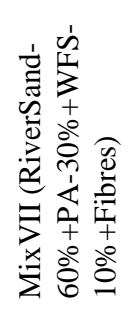 &  &  &  \\
\hline Slump flow (mm) & 710 & 690 & 700 & 695 & 690 & 600 & 685 & 695 & 595 & $650-800$ \\
\hline T50cm slump ( $\mathrm{sec}$ ) & 3.23 & 3.35 & 3.25 & 3.40 & 3.45 & 6.00 & 3.50 & 3.80 & 6.25 & $2-5$ \\
\hline J Ring ( sec ) & 9 & 6 & 7 & 7 & 6 & 12 & 9 & 7 & 14 & $6-12$ \\
\hline V Funnel ( sec ) & 8.12 & 8.20 & 8.25 & 8.5 & 8.5 & 12.2 & 8.3 & 8.4 & 13 & $0-10$ \\
\hline $\mathrm{V}$ funnel $\mathrm{T} 5 \mathrm{~min}(\mathrm{~mm})$ & 2 & 2 & 2 & 2.5 & 2.65 & 3.20 & 2.40 & 2.60 & 3.60 & $0-3$ \\
\hline L Box & 0.93 & 0.98 & 0.88 & 0.84 & 0.86 & 0.70 & 0.83 & 0.81 & 0.75 & $0.8-1.0$ \\
\hline \multirow[t]{2}{*}{ EFNARC } & $\mathrm{S}$ & $\mathrm{S}$ & $\mathrm{s}$ & $\mathrm{S}$ & $\mathrm{S}$ & NS & $\mathrm{S}$ & $\mathrm{S}$ & NS & - \\
\hline & \multicolumn{10}{|c|}{$S-$ EFNARC Satisfied } \\
\hline
\end{tabular}




\section{COMPRESSIVE STRENGTH}

Concrete cubes of size $150 \mathrm{~mm} \times 150 \mathrm{~mm} \times 150 \mathrm{~mm}$ were cast, cured for 7 days and 28 days in potable water and tested for compressive strength in a compression testing machine. The optimum replacement of river sand using pond ash in self compacting concrete was $30 \%$ based on the experimental results. The effect of different levels of foundry sand used as a replacement for natural river sand with $30 \%$ Pond ash on fibre reinforced self compacting concrete was found out. The 7 days and 28 days compressive strength of various mixes of SCC are shown in Table 5

Table 5. 7 Days and 28 Days Compressive Strength of specimen

\begin{tabular}{|l|l|l|}
\hline Mix Designation & $\begin{array}{l}\text { 7 Days } \\
\left(\mathbf{N} / \mathbf{m m}^{\mathbf{2}}\right)\end{array}$ & $\begin{array}{l}\mathbf{2 8} \text { Days } \\
\left(\mathbf{N} / \mathbf{m m}^{2}\right)\end{array}$ \\
\hline Mix I (Riversand-100\%) & 25.09 & 39.00 \\
\hline MixII (Riversand-100\%+Fibres) & 25.10 & 38.92 \\
\hline $\begin{array}{l}\text { MixVII (RiverSand-60\%+PA- } \\
\text { 30\%+WFS-10\%+Fibres) }\end{array}$ & 24.86 & 39.11 \\
\hline $\begin{array}{l}\text { MixVIII(RiverSand-50\%+PA- } \\
\text { 30\%+WFS-20\%+Fibres) }\end{array}$ & 25.20 & 39.24 \\
\hline $\begin{array}{l}\text { Mix IX(RiverSand-40\%+PA- } \\
\text { 30\%+WFS-30\%+Fibres) }\end{array}$ & 23.01 & 36.58 \\
\hline
\end{tabular}

Higher compressive strength of self compacting concrete at 7 and 28 days was obtained when the replacement level of pond ash was $30 \%$ and foundry sand was $20 \%$. It can be observed that $30 \%$ pond ash and $20 \%$ waste foundry sand can be used as a replacement for river sand in self compacting concrete without decrease in the compressive strength when compared to the conventional self compacting concrete. When $30 \%$ Pond ash and $30 \%$ waste foundry sand was used as replacement for river sand in self compacting concrete, there was a decrease in the compressive strength at 7 days and 28 days when compared to the conventional self compacting concrete. Figures 6a) and 6b) show the compressive strength of SCC at 7 days and 28 days respectively. The comparison of the compressive strength of SCC at 7 days and 28 days is shown in Figure 7.

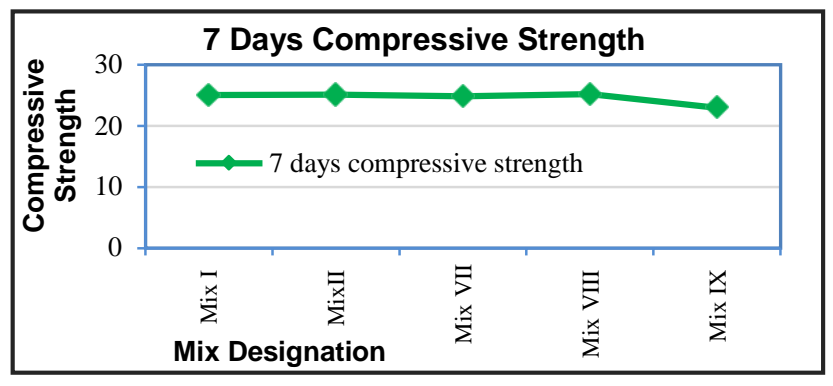

Fig.6(a).7 Days Compressive Strength of SCC

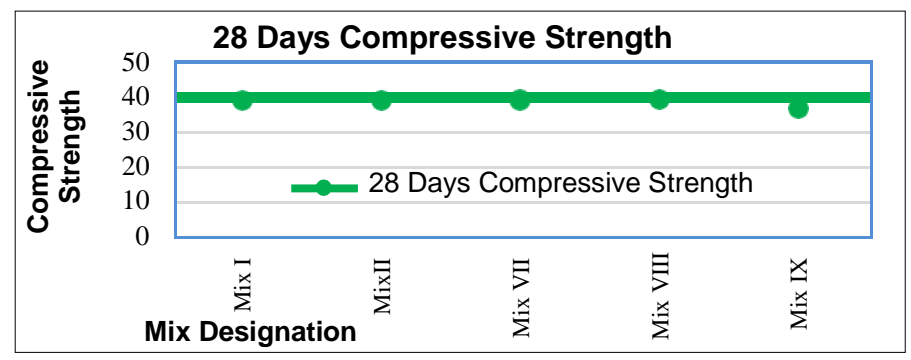

Fig. 6 b) 28 Days Compressive Strength of SCC

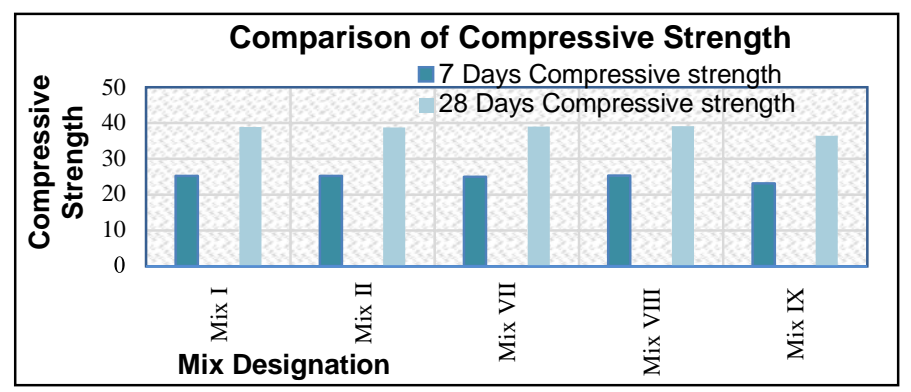

Fig. 7. Comparison of Compressive Strength of SCC at 7 Days and 28 Days

\section{SPLIT TENSILE STRENGTH}

Concrete cylinders of size $150 \mathrm{~mm}$ diameter and 300mm length cast, cured for 7 days and 28 days in potable water and tested for split tensile strength. The 7 days and 28 days Split tensile strength values of various mixes of SCC are shown in Table 6.

Table 6. 7 Days and 28 Days Split Tensile strength

\begin{tabular}{|c|c|c|}
\hline Mix Designation & $\begin{array}{c}\text { 7Days } \\
\left(\mathbf{N} / \mathbf{m m}^{2}\right)\end{array}$ & $\begin{array}{l}28 \text { Days } \\
\left(\mathrm{N} / \mathbf{m m}^{2}\right)\end{array}$ \\
\hline Mix I (Riversand-100\%) & 2.56 & 3.94 \\
\hline MixII(Riversand-100\%+Fibres) & 2.88 & 4.14 \\
\hline $\begin{array}{l}\text { MixVII (RiverSand-60\%+PA-30\%+WFS- } \\
10 \%+\text { Fibres) }\end{array}$ & 2.65 & 4.08 \\
\hline $\begin{array}{l}\text { MixVIII(RiverSand-50\%+PA- } \\
30 \%+\text { WFS-20\%+Fibres) }\end{array}$ & 2.70 & 4.15 \\
\hline $\begin{array}{l}\text { Mix IX(RiverSand- } 40 \%+\text { +PA-30\%+WFS- } \\
30 \%+\text { Fibres) }\end{array}$ & 2.44 & 3.86 \\
\hline
\end{tabular}

Addition of polypropylene fibres to the conventional SCC have have increased the split tensile strength by $10 \%$ at 7 days and $5 \%$ at 28 days in SCC and it was the maximum split tensile strength of all the mixes. When $30 \%$ pond ash and $30 \%$ waste foundry sand was used as replacement for river sand in self compacting concrete, there was a decrease in the split tensile strength at 7 days and 28 days when compared to the conventional self compacting concrete. However, it was observed that the split tensile strength was $5.4 \%$ higher at 7 days and 28 days when $30 \%$ Pond ash and $20 \%$ waste foundry sand were used as replacement for river sand in self compacting concrete when compared to the conventional self compacting concrete. The Mix VIII of M30 grade fibre reinforced self compacting concrete obtained at 30\% Pond ash and $20 \%$ foundry sand used as replacement for river sand with $25 \%$ of GGBS as a replacement of cement and $1.00 \mathrm{~kg} / \mathrm{m}^{3}$ fibres 
International Journal of Engineering Research and Technology. ISSN 0974-3154, Volume 13, Number 9 (2020), pp. $2365-2373$

(C) International Research Publication House. https://dx.doi.org/10.37624/IJERT/13.9.2020.2365-2373

has the maximum compressive strength and tensile strength than the conventional self compacting concrete. The split tensile strength of SCC at 7 days and 28 days is shown in Figures 8 a) and 8 b) respectively. The comparison of the split tensile strength of SCC at 7 days and 28 days is shown in Figure 9.

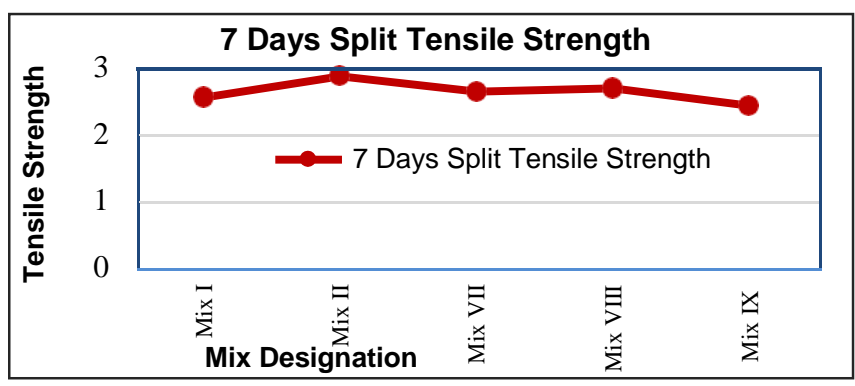

Fig. 8a) 7 Days Split Tensile Strength of SCC

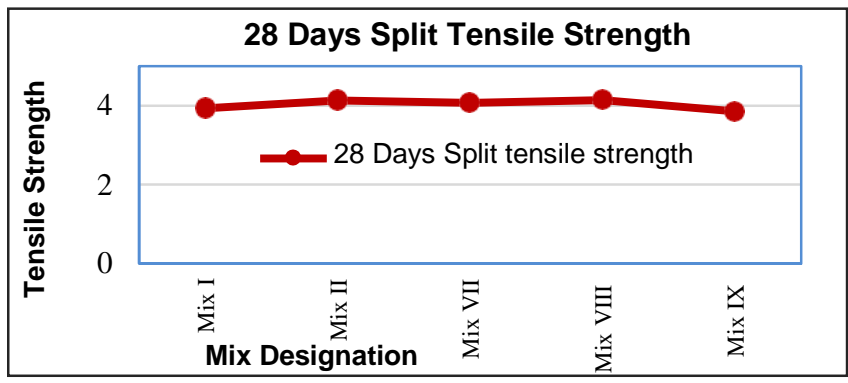

Fig. 8(b) 28 Days Split Tensile Strength of SCC

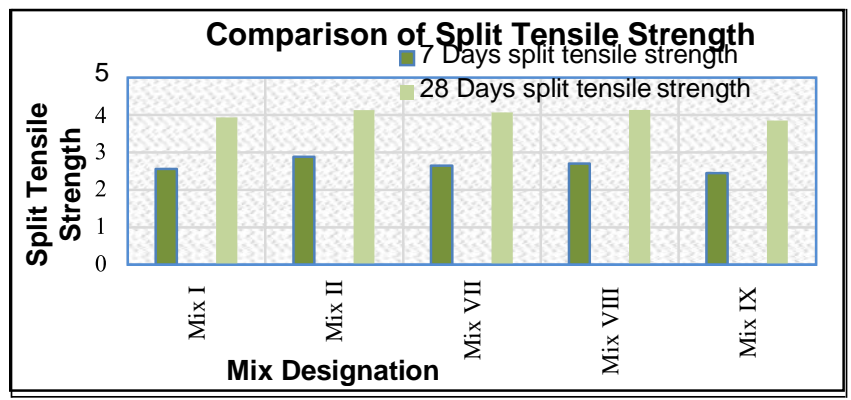

Fig.9. Comparison of Split Tensile Strength of SCC at 7 Days and 28 Days

\section{FLEXURAL STRENGTH}

The flexural test was carried out on beam specimens of size $100 \times 100 \times 400 \mathrm{~mm}$ to determine the flexural strength of the specimens. The specimens were subjected to two-point loading. The 7 days and 28 days flexural strength values of various mixes of SCC are tabulated in Table 7

Table 7.Flexural Strength of Concrete prisms

\begin{tabular}{|l|c|c|}
\hline \multicolumn{1}{|c|}{ Mix Designation } & $\begin{array}{c}\text { 7Days } \\
\text { (N/mm2) }\end{array}$ & $\begin{array}{c}\text { 28 Days } \\
\text { (N/mm2) }\end{array}$ \\
\hline Mix I (Riversand-100\%) & 3.14 & 4.84 \\
\hline MixII (Riversand-100\%+Fibres) & 3.23 & 4.98 \\
\hline $\begin{array}{l}\text { MixVII (RiverSand-60\%+PA- } \\
\text { 30\%+WFS-10\%+Fibres) }\end{array}$ & 3.09 & 4.76 \\
\hline $\begin{array}{l}\text { MixVIII(RiverSand-50\%+PA- } \\
\text { 30\%+WFS-20\%+Fibres) }\end{array}$ & 2.88 & 4.69 \\
\hline $\begin{array}{l}\text { Mix IX(RiverSand-40\%+PA- } \\
\text { 30\%+WFS-30\%+Fibres) }\end{array}$ & 2.56 & 3.94 \\
\hline
\end{tabular}

The addition of fibres to the conventional SCC have increased the flexural strength at 7 days and 28 days by $3 \%$ in SCC and it was the Maximum flexural strength of all the mixes. However, it was observed that when $30 \%$ Pond ash and $10 \%$ waste foundry sand were used as replacement for river sand in self compacting concrete there was a marginal decrease in the flexural strength of self compacting concrete when compared to the conventional self compacting concrete at 7 days and 28 days. The Mix VIII of M30 grade fibre reinforced self compacting concrete obtained at $30 \%$ Pond ash and $20 \%$ foundry sand as replacement for river sand with $25 \%$ of GGBS as a replacement of cement and $1.00 \mathrm{~kg} / \mathrm{m}^{3}$ fibres has a marginal decrease of $3 \%$ when compared to the conventional self compacting concrete at 28 days. Figures 10 a) and $10 \mathrm{~b}$ ) show the flexural strength of SCC at 7 days and 28 days respectively. The comparison of the flexural strength of M30 grade of SCC at 7 days and 28 days is shown in Figure 11

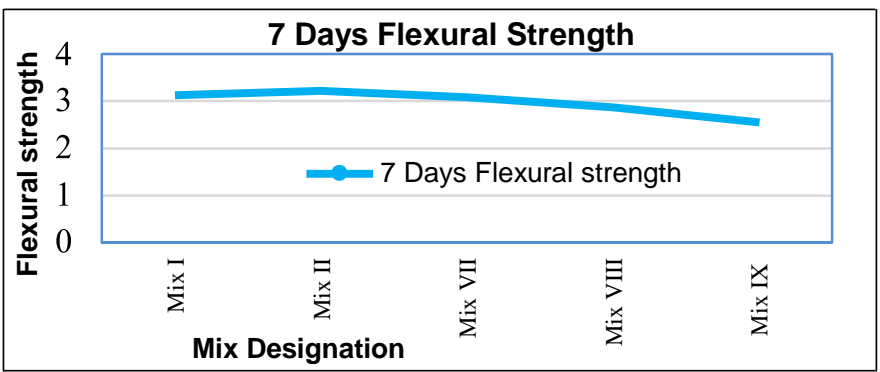

Fig. 10 a). Flexural Strength of SCC at 7 Days

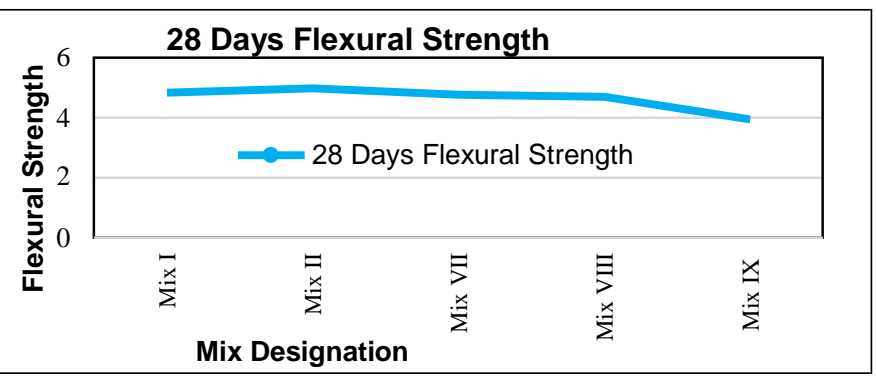

Fig.10 b). Flexural Strength of SCC at 28 Days

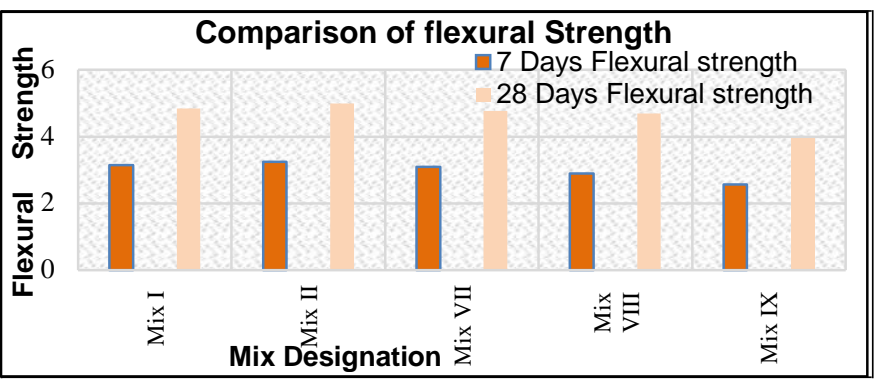

Fig. 11. Comparison of Flexural Strength of SCC at 7Daysand 28 Days

The 28 days flexural strength of M30 grade FRSCC with optimum percentage replacement of pond ash, waste foundry sand and normal river sand are tabulated in Table 8. Table 9 shows the percentage increase in strength with the optimum dosage of fibres. 
International Journal of Engineering Research and Technology. ISSN 0974-3154, Volume 13, Number 9 (2020), pp. $2365-2373$

(C) International Research Publication House. https://dx.doi.org/10.37624/IJERT/13.9.2020.2365-2373

Table 8. 28 Days Strength of M 30 grade FRSCC with optimum PA, WFS AND NRS

\begin{tabular}{|c|c|c|c|c|}
\hline$\stackrel{\gtreqless}{\leftrightarrows}$ & Specimen Designation & 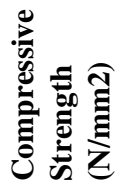 & 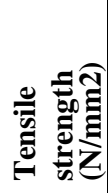 & 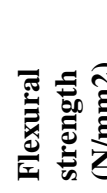 \\
\hline 1 & $\begin{array}{l}\text { Mix I } \\
\text { (Riversand-100\%) }\end{array}$ & 39.00 & 3.94 & 4.84 \\
\hline 2. & $\begin{array}{l}\text { Mix II } \\
\text { (Riversand-100\%+Fibres) }\end{array}$ & 38.92 & 4.14 & 4.98 \\
\hline 3. & $\begin{array}{l}\text { MixVII } \\
\text { (RiverSand-60\%+PA- } \\
30 \%+\text { WFS-10\%+Fibres) }\end{array}$ & 39.11 & 4.08 & 4.76 \\
\hline 4. & $\begin{array}{l}\text { Mix VIII } \\
\text { (RiverSand-50\%+PA- } \\
30 \%+\text { WFS-20\%+Fibres) }\end{array}$ & 39.24 & 4.15 & 4.69 \\
\hline
\end{tabular}

It can be observed from Table 8 that the Mix VIII, fibre reinforced self compacting concrete obtained with $30 \%$ Pond ash and $20 \%$ foundry sand used as replacement for river sand and $25 \%$ of GGBS as a replacement of cement and $1.00 \mathrm{~kg} / \mathrm{m}^{3}$ fibres has the maximum compressive strength and split tensile strength with a marginal decrease in flexural strength by $3 \%$ when compared to the conventional self compacting concrete at 28 days.

Table 9. Percentage increase in Strength with the optimum dosage of fibres

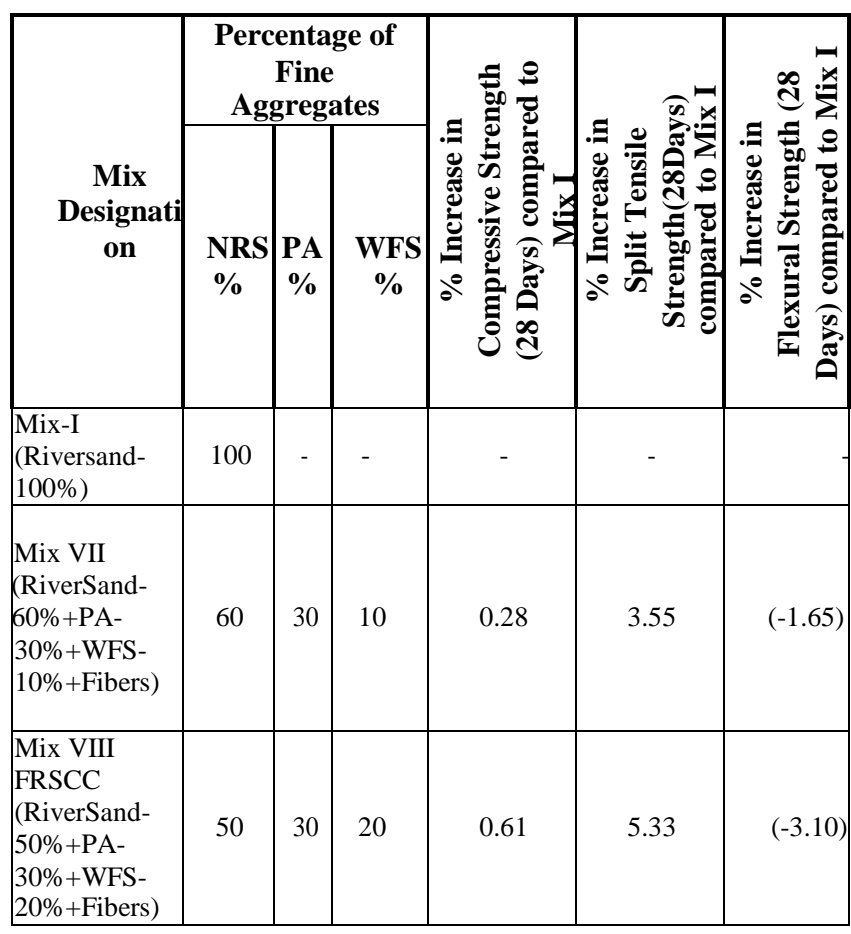

\section{VIII . DURABILITY TESTS}

\section{A. Acid attack test}

Acid attack test was performed for all the five mixes at 28 days. $150 \mathrm{~mm}$ cube specimens of concrete were cast and after 28 days of water curing, the weights of concrete cube specimen were taken. The acid attack test on concrete cubes were conducted by immersing the cubes in
$5 \%$ weight of Hydrochloric acid (HCL) added with water. After 28 days, the cubes were taken from acid, the weight of the specimen, compressive strength and the \% reduction in weight were determined. The results obtained were tabulated in Table 10.

Table 10. Percentage loss in weight and compressive Strength due to Acid attack

\begin{tabular}{|c|c|c|c|c|c|c|c|}
\hline \multirow[b]{2}{*}{$\stackrel{\varrho}{\omega}$} & \multirow[b]{2}{*}{ Mix Dezzsignation } & \multicolumn{2}{|c|}{$\begin{array}{l}\text { Weight } \\
\text { of cubes } \\
\text { (kg) }\end{array}$} & \multirow{2}{*}{ 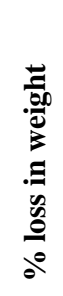 } & \multicolumn{2}{|c|}{$\begin{array}{l}\text { Compressive } \\
\text { strength }\end{array}$} & \multirow{2}{*}{ 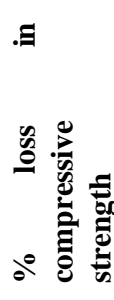 } \\
\hline & & 递 & 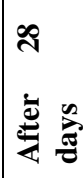 & &  & 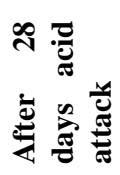 & \\
\hline 1 & $\begin{array}{l}\text { Mix I (Riversand- } \\
100 \%)\end{array}$ & 8.390 & 8.104 & 3.41 & 39.00 & 36.30 & 6.92 \\
\hline 2 & $\begin{array}{l}\text { MixII(Riversand- } \\
\text { 100\%+Fibres) }\end{array}$ & 8.382 & 8.100 & 3.36 & 38.92 & 36.28 & 6.78 \\
\hline 3 & $\begin{array}{l}\text { MixVII(RiverSand- } \\
60 \%+\text { PA-30\%+WFS- } \\
10 \%+\text { +Fibres) }\end{array}$ & 8.245 & 8.007 & 2.89 & 39.11 & 37.06 & 5.24 \\
\hline 4 & $\begin{array}{l}\text { MixVIII(RiverSand- } \\
50 \%+\text { PA-30\%+WFS- } \\
\text { 20\%+Fibres) }\end{array}$ & 8.00 & 7.778 & 2.77 & 39.24 & 37.25 & 5.07 \\
\hline 5 & $\begin{array}{l}\text { Mix IX(RiverSand- } \\
40 \%+\text { +PA-30\%+WFS- } \\
30 \%+\text { +Fibres) }\end{array}$ & 7.916 & 7.670 & 3.10 & 36.58 & 34.21 & 6.47 \\
\hline
\end{tabular}

The percentage loss in weight and percentage loss in compressive strength at 28 days with acid attack was found to be maximum for Self compacting concrete with river sand as fine aggregate (Mix I). It was observed that the minimum reduction in weight and compressive strength was $3 \%$ and $5.1 \%$ for self compacting concrete with $30 \%$ Pond ash and $20 \%$ waste foundry sand used as replacement for river sand. The reduction in the acid attack values was due to the presence of more amount of internal voids that has been filled up by the use of pond ash and foundry sand in Mix VIII. The loss of weight and compressive strength for Mix VII with $30 \%$ Pond ash and $10 \%$ waste foundry sand used as replacement for river sand in self compacting concrete was $3.3 \%$ more when compared to Mix VIII. When $30 \%$ Pond ash and $30 \%$ waste foundry sand was used as replacement for river sand in self compacting concrete, there was an increase in $11.91 \%$ loss of weight and $27.6 \%$ loss in compressive strength of concrete. Figures 12 a) and 12 b) show the Percentage loss in weight and percentage loss in Compressive strength of various mixes of SCC respectively.

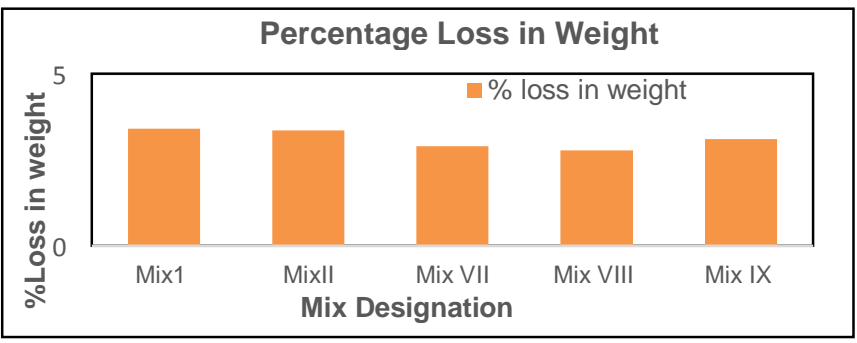

Fig. 12 a). Variation of Percentage Loss in Weight due to Acid attack 


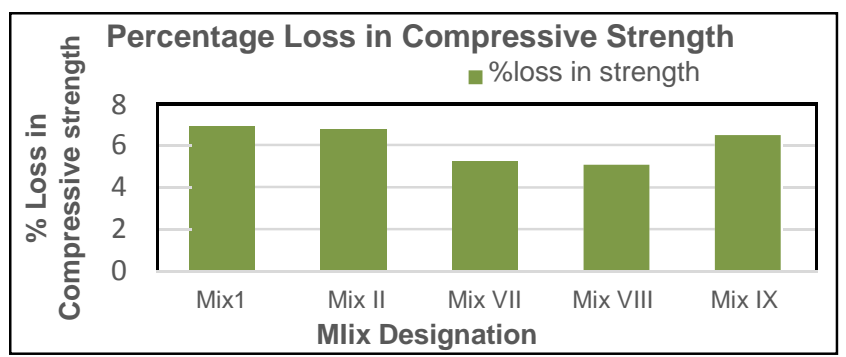

Fig. 12 b). Variation of Percentage Loss in

Compressive Strength due to Acid attack

\section{B.. Water absorption Test}

Water absorption test was performed for all the five mixes at 28 days. $150 \mathrm{~mm}$ cube specimens of concrete were cast and after 28 days of water curing, the weights of concrete cube specimens were taken.. The air dried specimens were placed in an oven until constant weight was obtained. Then the specimens were placed in clean water for a period of 24 hours and weighed. The results obtained are tabulated in Table 11 Table 11. Percentage of Water Absorption for Different Mixes of Concrete

\begin{tabular}{|c|c|c|c|c|}
\hline \multirow[t]{2}{*}{ Sl.no } & \multirow[t]{2}{*}{ Mix Desig nation } & \multicolumn{2}{|c|}{$\begin{array}{l}\text { Weight of } \\
\text { cubes }(\mathrm{kg})\end{array}$} & \multirow{2}{*}{$\begin{array}{l}\% \text { of } \\
\text { water } \\
\text { absorption }\end{array}$} \\
\hline & & Dry & Wet & \\
\hline 1 & Mix I (Riversand-100\%) & 8.19 & 8.39 & 2.44 \\
\hline 2 & $\begin{array}{l}\text { MixII } \\
100 \%+\text { Fibres) }\end{array}$ & 8.25 & 8.41 & 1.94 \\
\hline 3 & $\begin{array}{l}\text { MixVII (RiverSand- } \\
60 \%+\text { +PA-30\%+WFS- } \\
10 \%+\text { +Fibres) }\end{array}$ & 8.18 & 8.33 & 1.83 \\
\hline 4 & $\begin{array}{l}\text { MixVIII(RiverSand- } \\
50 \%+\text { PA-30\%+WFS- } \\
20 \%+\text { +Fibres) }\end{array}$ & 7.91 & 8.04 & 1.64 \\
\hline 5 & $\begin{array}{l}\text { MixIX (RiverSand- } \\
40 \%+\text { +PA-30\%+WFS- } \\
30 \%+\text { +Fibres) }\end{array}$ & 7.85 & 7.97 & 1.53 \\
\hline
\end{tabular}

The percentage of water absorption was found to be maximum for Mix I. It was observed that the minimum water absorption was $37 \%$ lesser when compared to Mix 1 obtained when $30 \%$ Pond ash and $30 \%$ waste foundry sand was used as replacement for river sand in self compacting concrete. The water absorption of SCC with polypropylene fiber was less than the plain SCC due to the non polar structure of the fiber.It was observed that the water absorption decreased with an increase of foundry sand replacement. Good compaction is achieved as an additional advantage for reduction in water absorption. The pozzolanic activity of pond ash showed higher resistance to water absorption. Foundry sand reduced the pores present in the concrete and therefore the water absorption decreased with an increase in foundry sand replacement. Figure 13 shows the Percentage of water absorption of various mixes of SCC.



Fig. 13. Percentage variation of Water Absorption of Concrete subjected to water absorption test

\section{C.Sulphate Attack Test}

Sulphate attack test was performed for all the five mixes at 28 days. $150 \mathrm{~mm}$ cube specimens of concrete were cast and after 28 days of water curing, the weights of concrete cube specimen were taken. The sulphate attack test on concrete cubes were conducted by immersing the cubes in $5 \%$ weight of $\mathrm{Na}_{2} \mathrm{SO}_{4}$ solution added with water. After 28 days, the cubes were taken from the sulphate water, the weight of the specimen, compressive strength and the $\%$ reduction in weight were determined. The detail results are shown in Table 12.

Table 12. Loss in weight and compressive Strength in Percentage due to Sulphate attack

\begin{tabular}{|c|c|c|c|c|c|c|c|}
\hline \multirow[b]{2}{*}{$\stackrel{9}{\mathscr{n}}$} & \multirow{2}{*}{ 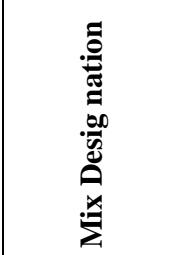 } & \multicolumn{2}{|c|}{$\begin{array}{l}\text { Weight of } \\
\text { cubes (kg) }\end{array}$} & \multirow{2}{*}{ 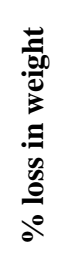 } & \multicolumn{2}{|c|}{$\begin{array}{l}\text { Compressive } \\
\text { strength }\end{array}$} & \multirow{2}{*}{ 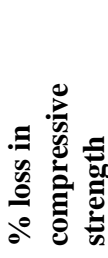 } \\
\hline & & : &  & & $\frac{0}{0}$ & 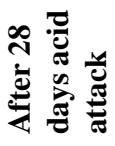 & \\
\hline 1 & $\begin{array}{l}\text { Mix I } \\
\text { (Riversand- } \\
100 \% \text { ) }\end{array}$ & 8.386 & 8.209 & 2.11 & 39.00 & 36.72 & 5.84 \\
\hline 2 & $\begin{array}{l}\text { MixII } \\
\text { (Riversand- } \\
\text { 100\%+Fibres) }\end{array}$ & 8.380 & 8.206 & 2.07 & 38.92 & 36.89 & 5.21 \\
\hline 3 & $\begin{array}{l}\text { MixVII } \\
\text { (RiverSand- } \\
60 \%+\text { PA- } \\
30 \%+\text { WFS- } \\
10 \%+\text { Fibres) }\end{array}$ & 8.235 & 8.082 & 1.86 & 39.11 & 37.38 & 4.42 \\
\hline 4 & $\begin{array}{l}\text { MixVIII(Rive } \\
\text { rSand- } \\
50 \%+\text { PA- } \\
30 \%+\text { WFS- } \\
20 \%+\text { Fibres) }\end{array}$ & 8.020 & 7.875 & 1.80 & 39.24 & 37.68 & 3.97 \\
\hline 5 & $\begin{array}{l}\text { Mix } \\
\text { IX(RiverSand } \\
-50 \%+\text { PA- } \\
30 \%+\text { WFS- } \\
20 \%+\text { Fibres) }\end{array}$ & 7.910 & 7.723 & 2.36 & 36.58 & 34.50 & 5.69 \\
\hline
\end{tabular}

The percentage weight loss and percentage loss in compressive strength are less in sulphate attack than acid attack. The percentage loss in weight at 28 days for Mix IX with Sulphate attack was found to be maximum. The minimum reduction in weight and compressive strength was observed for self compacting concrete with $30 \%$ Pond ash and $20 \%$ waste foundry sand used as replacement for river sand(Mix VIII). The decrease in weight and compressive strength were $14 \%$ and $32 \%$ respectively when $30 \%$ Pond ash and $20 \%$ waste foundry sand were used as replacement for river sand in self compacting concrete compared to Mix 1(NSCC). The decrease in loss of compressive strength both in acid as well as sulphate attack was due to the presence of more amount of internal voids that has been filled up by the use of pond ash and foundry sand in Mix VIII. Figures 14 a) and 14 b) show the Percentage loss in weight and percentage loss in Compressive strength of various mixes of SCC respectively. 


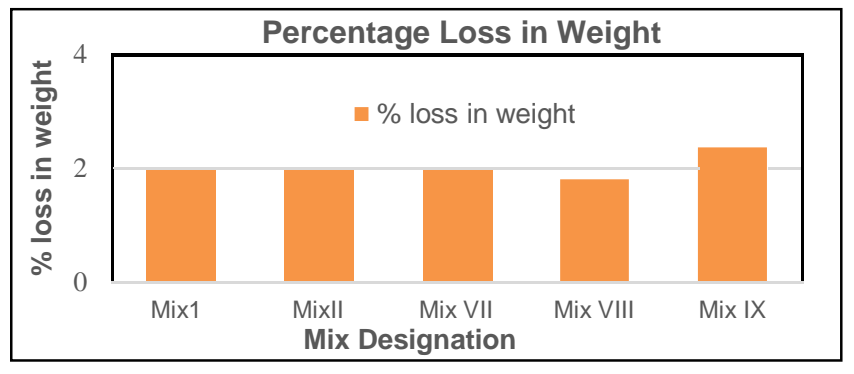

Fig. 14 a) Variation of Percentage Loss in w eight due to sulphate attack

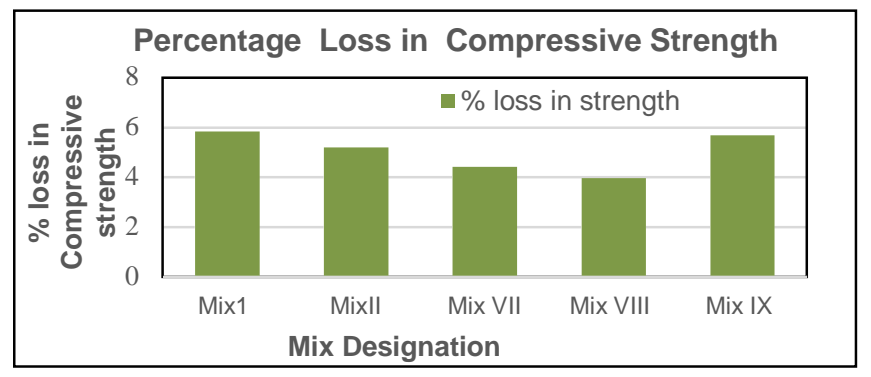

Fig. 14 b) Variation of Percentage Loss in Compressive Strength due to sulphate attack

SCC with $30 \%$ Pond ash and $20 \%$ foundry sand used as replacement for river sand exhibited good durability performance in terms of water absorption, acid attack and sulphate attack.

\section{CONCLUSIONS}

Mix VIII, fibre reinforced self compacting concrete obtained with $30 \%$ Pond ash and $20 \%$ foundry sand used as replacement for river sand and $25 \%$ of GGBS as a replacement of cement and $1.00 \mathrm{~kg} / \mathrm{m}^{3}$ fibres has the maximum compressive strength and split tensile strength and a marginal decrease in flexural strength by $3 \%$ when compared to the conventional self compacting concrete at 28 days. The compressive strength of Mix VIII (PA$30 \%+$ WFS-20\%) was maximum after additional 28 days of acid attack respectively. Mix VIII with PA-30\%+ WFS-20\% had the least percentage loss in weight (1.80\%) when exposed to sulphate attack for 28 days.

Mix IX with PA-30\%+WFS-30\% as replacement for river sand had the least weight at 28 days and the percentage loss in weight was more in this mix after 28 days of sulphate attack The compressive strength of Mix IX was the least after 28 days of curing and after 28 days of acid attack. Therefore the Mix IX is not suitable for construction.

SCC with $30 \%$ Pond ash and $20 \%$ foundry sand used as replacement for river sand exhibited good durability performance in terms of water absorption, acid attack and sulphate attack. So in heavily congested reinforcement structures and high rise buildings, this SCC mix proportion can be adopted

It can be concluded that the self-compacting concrete formed by partially replacing the natural fine aggregates with foundry sand and pond ash is found to be economical, durable and environment-friendly and can be effectively used in the construction industry.

\section{REFERENCES}

[1] EFNARC (2002). "The European guidelines and specification for selfcompacting concrete",www.efnarc.org.

[2] G.DeSchutter, "Guidelines for testing fresh self-compacting concrete" European research Project : Testing-SCC," 2005.

[3] H.Okamura ,M.Ouchi, "Self Compacting Concrete," Journal of Advanced Concrete Technology, vol. 1, pp. 5-15, 2003.

[4] Pai.B.H.V, Nandy M., K.H, Sarkar.P.K, Ganapathy.C.P, Arumugam.K, (2011), "A Study on Characterization and use of pond ash as fine aggregate in concrete", International Journal of Civil Engineering,Vol.2,No 2.

[5] Siddique R, de Schutter G, Noumowe A (2009) "Effect of used-foundry sand on the mechanical properties of con-crete". Constr Build Mater 23(2):976-980.

[6] Khatib , Ellis DJ (2001) "Mechanical properties of concretecontaining foundry sand". ACI Spec Publ SP-200:733-748

[7] Fiore S, Zanetti MC (2007) "Foundry wastes reuse and recycling in concrete production". Am J Environ Sci 3(3):135-142 